\title{
JUSTYNA KULCZYK
}

Uniwersytet Gdański

Wydział Nauk Społecznych

Instytut Psychologii

e-mail: justyna.kulczyk@wp.pl

\section{EMPATIA I STYL PRZYWIĄZANIA W KONTEKŚCIE BLISKICH ZWIĄZKÓW MLODYCH DOROSEYCH}

\begin{abstract}
Abstrakt. W niniejszym artykule opisano związek między trójwymiarowym modelem empatii a stylami przywiązania w bliskich związkach młodych dorosłych. W badaniu wzięło udział 120 osób (60 kobiet i 60 mężczyzn; 38 związków kohabitacyjnych i 22 związki małżeńskie). Uczestnicy badania wypełnili następujące kwestionariusze: Skalę Wrażliwości Empatycznej (SWE) mierzącą empatyczną troskę, osobistą przykrość i przyjmowanie perspektywy oraz Kwestionariusz Stylów Przywiązaniowych (KSP) mierzący przynależność do jednego ze stylów: bezpiecznego, lękowo-ambiwalentnego oraz unikowego. Wyniki badania wskazują istnienie związku między empatią a stylami przywiązania. Styl bezpieczny dodatnio koreluje z wymiarem przyjmowania perspektywy, styl lękowo-ambiwalentny dodatnio koreluje z wymiarem empatycznej troski i osobistej przykrości, a styl unikowy koreluje dodatnio z osobistą przykrością i ujemnie koreluje z przyjmowaniem perspektywy. Badania wykazały następujące różnice płciowe: wyższe wyniki w wymiarach empatycznej troski i osobistej przykrości osiągnęły kobiety aniżeli mężczyźni. Nie stwierdzono różnic płciowych $\mathrm{w}$ przejawianych stylach przywiązaniowych. Ponadto rodzaj związku (małżeństwo vs. kohabitacja) różnicował wyniki w stylu lękowo-ambiwalentnym oraz w wymiarze osobistej przykrości, w których kohabitanci uzyskali wyższe wyniki.
\end{abstract}

Słowa kluczowe: style przywiązania, empatia.

\section{WPROWADZENIE}

Teoria przywiązania, której twórcą jest John Bowlby, interdyscyplinarnie wyjaśnia kształtowanie się bliskich związków międzyludzkich. Przywiązanie rozwija się od okresu wczesnego dzieciństwa (Bowlby, 2007) i ewoluuje w perspektywie całego życia (Józefik, Iniewicz, 2008). Charakter rozwoju stylu przywiązania w okresie niemowlęctwa, definiowany w kontekście stopnia poczucia zaufania i bezpieczeństwa, wpływa na zachowanie jednostki przez całe życie, w tym także na to, jaki charakter i przebieg będą miały związki w życiu dorosłym (Rostowski, 2003).

Reakcja opiekuna na wszelkiego rodzaju emocjonalne zachowania niemowlęcia kształtuje w nim umiejętność samoregulacji oraz regulacji emocji 
w kontaktach z innymi osobami (Plopa, 2016). Jest zatem jednym z ważniejszych predyktorów emocjonalnego funkcjonowania w życiu dorosłym. Zróżnicowane zachowanie opiekuna wzbudza oraz kształtuje różnice w emocjonalnym rozwoju potomstwa (Feldman i in., 1999; Tarabulsy i in. 1996). Zaspokojone potrzeby emocjonalne w okresie dzieciństwa, w wyniku bezpiecznych, uczuciowych więzi z rodzicami, mogą przyczyniać się do rozwijania prawidłowych reakcji na potrzeby innych ludzi (Davis, 1999). Zatem wczesna socjalizacja, która stwarza poczucie bezpieczeństwa, sprzyja wzrostowi dyspozycyjnej empatii. Badania $\mathrm{z}$ udziałem dzieci dotyczące reagowania empatycznego $\mathrm{w}$ związku z poszczególnymi stylami przywiązania wykazały, że dzieci z przywiązaniem bezpiecznym w przeciwieństwie do dzieci z przywiązaniem unikającym (ale nie lękowo-ambiwalentnym) wykazały większe skłonności do współodczuwania cierpienia rówieśników oraz okazywały większe zainteresowanie i oferowanie pocieszenia (Kestenbaum i in. 1989; Waters i in. 1979).

Teoria Cindy Hazan i Philip Shavera (1994) wykazuje, że style przywiązania, łączące niemowlęta ze znaczącymi dla nich osobami, mają wpływ na jakość więzi między partnerami w dorosłym życiu. Założenia koncepcji ujawniają mechanizm biologiczny (behawioralny system przywiązania), który steruje emocjonalną i behawioralną dynamiką relacji, zarówno w przypadku relacji niemowlę-opiekun, jak i w przypadku romantycznych związków osób dorosłych. Zatem, według badaczy, miłość romantyczna okresu dorosłości jest oparta na procesie przywiązaniowym oraz na indywidualnych zróżnicowaniach, analogicznych do tych, które występują między dzieckiem a matką w okresie niemowlęctwa (za: Plopa, 2003). Badacze dokonali rozróżnienia trzech stylów przywiązania w związkach romantycznych, analogicznie do propozycji Ainsworth (1977), badającej zachowania niemowląt, a mianowicie: stylu bezpiecznego, lękowo-ambiwalentnego oraz unikowego.

Na podstawie licznych badań i doniesień literatury można zarysować zróżnicowany profil psychologiczny partnerów związków romantycznych, reprezentujących poszczególne style przywiązania (Rostowski, 2003). Osoby o bezpiecznym stylu przywiązania cechują się satysfakcją z bliskiej i intymnej relacji wytwarzanej w interakcji z partnerem. Cechują się wsparciem, wyrozumiałością, stabilnością oraz nasyceniem pozytywnymi emocjami (Kaźmierczak, Plopa, 2006; Rostowski, 2003; Wojciszke, 2004). Ponadto osoby takie charakteryzuje wyższy poziom zaufania i znacznie niższy poziom konfliktów niż osoby przywiązane pozabezpiecznie. Przywiązanie lękowo-ambiwalentne przejawia się nasiloną potrzebą bliskości, wysokim lękiem przez odrzuceniem i niskim poziomem zaufania. Osoby o lękowo-ambiwalentnym przywiązaniu przejawiają niepokój o trwałość relacji oraz obawę przed utratą partnera (Plopa, 2016). Tego typu uczucia panujące $\mathrm{w}$ związku mogą powodować pojawienie się dystansu emocjonalnego pomiędzy partnerami, co z kolei łączy się z niskim poziomem satysfakcji i zadowolenia ze związku. Związek z osobą przywiązaną ambiwalentnie obfituje w niepokój wywołany w głównej mierze lękiem przed porzuceniem 
i różnego rodzaju wątpliwościami. Osoby z unikającym stylem przywiązania charakteryzują się niskim zaufaniem w stosunku do partnera, niską chęcią lub całkowitym brakiem chęci emocjonalnego angażowania w związek (Liberska, Suwalska, 2011; Rostowski, 2003). Czują się niepewnie w sytuacji zależności, intymności i wsparcia. Osoby z unikającym wzorcem przywiązania często angażują się w pracę, która staje się dla nich możliwością ucieczki od bliskich relacji interpersonalnych (Rostowski 2003).

Badania Miculincera (1998) wykazały, że osoby o bezpiecznym stylu przywiązania, w związku romantycznym, okazują otwartą, nieegoistyczną oraz pełną troski postawę $\mathrm{w}$ stosunku do partnera. W związku z powyższym, osoby takie cechują się aktywnym działaniem na rzecz poprawy dobrostanu swojego partnera, a nie, jak w przypadku pozabezpiecznych stylów przywiązania, biernym i egocentrycznym oczekiwaniem na jego wsparcie. Badania wykazały także, że zarówno w przypadku osób o unikowym, jak i lękowo-ambiwalentnym stylu przywiązania, dominującą cechą w związku był brak zaufania. Różnica występowała jedynie w kwestii technik radzenia sobie z nadużyciem zaufania przez partnera. Otóż osoby unikowe dążyły do poczucia kontroli nad partnerem, natomiast osoby lękowo-ambiwalentne dążyły do poczucia bezpieczeństwa. W przypadku, gdy partner wykazywał negatywne zachowanie, partnerzy unikowi dystansowali się, natomiast partnerzy lękowi wykazywali wysoki poziom zamartwiania się (Plopa, 2016).

Intymność w relacjach partnerskich jest czynnikiem warunkującym bliskość, dobrostan, emocjonalne wsparcie, wyrozumiałość oraz zaufanie partnerów względem siebie. Intymność, obok namiętności i zaangażowania, składają się na trójczynnikową koncepcję miłości Roberta Sternberga (1986, 1997, 2001). Badania Bogdana Wojciszke (2014) ukazują dynamikę zmian natężenia komponentów miłości w zależności od poszczególnych faz trwania związku. W fazie związku kompletnego obecne są wszystkie trzy składniki miłości, a zatem jest to faza związku, która przynosi najwięcej satysfakcji partnerom. W związku kompletnym partnerzy przeżywają wspólnie troski i radości, ale przede wszystkim w tej fazie szczególną rolę spełnia empatia, dzięki której partnerzy wykazują umiejętność przyjmowania punktu widzenia partnera oraz emocjonalne współbrzmienie (Wojciszke, 2014).

Empatia definiowana jest w kontekście zawieszania jednoogniskowej koncentracji uwagi (single-minded) i przyjmowania perspektywy dwuogniskowej (double-minded) (Baron-Cohen, 2014). Pod pojęciem „uwagi jednoogniskowej” ukrywają się intrapersonalne funkcje, takie jak: skupianie się na wewnętrznych przeżyciach, myślach oraz spostrzeżeniach. Natomiast „uwaga dwuogniskowa” opisywana jest jako zdolność wyodrębnienia stanu własnego umysłu od umysłu drugiego człowieka, a zatem jest to zdolność do podwójnej koncentracji uwagi. Podejście definicyjne Baron-Cohena podkreśla dwoisty charakter empatii polegający na rozpoznawaniu stanów emocjonalnych i reagowaniu na nie. Zatem wystąpienie właściwej emocji (rozpoznanie) bez adekwatnej reakcji jest niewystarczające do zdefiniowania zachowania jako empatia. Empatia musi być ,,pełnoobjawowa”, 
a więc poza rozpoznaniem uczuć i zachowania innej osoby ważnym czynnikiem jest także zareagowanie na nie odpowiednią emocją. Rozwinięta empatia umożliwia zawieranie głębszych i trwalszych kontaktów interpersonalnych, przyjaźni. Umiejętność odczytywania intencji innych ludzi pozwala na uniknięcie nieporozumień i zakłóceń komunikacyjnych.

Inspiracją do badań zawartych w niniejszym artykule było wielowymiarowe ujęcie empatii zaproponowane przez Marka H. Davisa (1980, 1983, 1999). Według Davisa (1999), empatia definiowania jest jako kognitywny proces zachodzący u obserwatora cudzej sytuacji (przyjmowanie perspektywy) oraz pojawiające się w jego następstwie skutki o charakterze afektywnym (osobista przykrość i empatyczna troska) i nieafektywnym. Zatem empatia jest konstruktem o charakterze emocjonalno-poznawczym. Jest także procesem uwarunkowanym sytuacyjnie (intensywność sytuacji, stopień podobieństwa między obserwatorem i obserwowanym) oraz jest czynnikiem związanym z osobą (zdolności biologiczne, różnice indywidualne, specyfika doświadczeń życiowych - emocjonalna jakość relacji rodzinnych, sposób przywiązania, dyspozycje empatyczne rodziców) (Czerniakowska, 2002). Davis (1999) wskazuje cechy dyspozycyjne jednostki, które przejawiają się w empatycznym myśleniu oraz postępowaniu, odzwierciedlające się $\mathrm{w}$ wyborze zachowań związanych z empatią.

Empatyczna troska jest współodczuwaniem w stosunku do innych osób znajdujących się w niekorzystnej sytuacji. Osobista przykrość jest stanem dyskomfortu (przyjmowanie cudzych negatywnych emocji) oraz poczuciem przykrości w związku z cierpieniem innych, natomiast przyjmowanie perspektywy jest spontaniczną skłonnością przyjmowania punktu widzenia innych (Kaźmierczak, 2008). Przeprowadzone w Polsce badania dotyczące par małżeńskich ukazały, że składniki empatii, tj. empatyczna troska i przyjmowanie perspektywy, osłabiają skłonności do zachowań deprecjonujących partnera, natomiast osobista przykrość wzmacnia te zachowania (Kaźmierczak, 2008).

Podstawę teoretyczną badań własnych stanowią wskazane w części teoretycznej koncepcje Hazan i Shavera opartej na teorii Bowlby'ego oraz wielowymiarowe ujęcie empatii Davisa.

\section{PROBLEM BADAWCZY}

Głównym celem badań referowanych w artykule było:

1. Wskazanie powiązań między dyspozycyjną empatią a stylami przywiązania.

2. Sprawdzenie efektu płci i rodzaju zawartego związku (małżeństwo/kohabitacja) dla poziomu empatii i stylów przywiązaniowych.

W związku z tak zdefiniowanymi głównymi celami badawczymi sformułowano hipotezy szczegółowe. 


\subsection{Style przywiązania a empatia}

Stosunki rodzinne, zwłaszcza z najbliższymi opiekunami, stwarzają większe poczucie bezpieczeństwa i wspomagają rozwój dyspozycyjnej empatii (Davis, 1999) oraz kształtują prawidłowy i bezpieczny styl przywiązania w dorosłym życiu. Na podstawie powyższych doniesień postawiono następującą hipotezę:

Hipoteza 1: Empatia partnerów jest bezpośrednio związana z przejawianymi stylami przywiązaniowymi.

Osoby o bezpiecznym stylu przywiązania powinny wykazywać wyższy poziom empatycznej troski. Powyższe założenie pośrednio zostało potwierdzone w badaniach Kestenbaum i współpracowników (1989) z udziałem dzieci, w których udowodniono, że dzieci bezpiecznie przywiązane były bardziej skłonne do współodczuwania cierpienia rówieśników. Badania Eisenberg i Fabes (1992) wykazują, że dwa składniki empatii - empatyczna troska i osobista przykrość - łączą się z silnym odczuwaniem cudzych emocji, ale w związku z komponentem osobistej przykrości u jednostki występują także niskie kompetencje samoregulacji doświadczanych emocji oraz wysoki poziom koncentracji na własnych emocjach (Pastwa-Wojciechowska i in., 2015). Odnosząc się do badań oraz do psychologicznych teorii, postawiono hipotezy dotyczące związku empatii z poszczególnymi kategoriami stylów. Przy tym uwzględniono specyfikę trzech komponentów empatii:

Hipoteza 1a: Empatyczna troska i przyjmowanie perspektywy wiążą się $\mathrm{z}$ bezpiecznym stylem przywiązania.

Hipoteza 1b: Osobista przykrość wiąże się z negatywnymi dla bliskich relacji stylami przywiązania, jak styl lękowo-ambiwalentny i unikowy.

\subsection{Płeć a empatia i style przywiązania}

Z przeglądu literatury przedmiotu wynika, że wymiary empatii, takie jak: empatyczna troska i przyjmowanie perspektywy, są powiązane z wymiarem płci psychologicznej - kobiecości (Davis, 1999). W przypadku płci męskiej dopatrzono się ujemnych korelacji z osobistą przykrością. Generalnie, doniesienia badań empirycznych wskazują na wyższy poziom empatii u kobiet (Davis, Oathout, 1987; Eisenberg, Lennon, 1983). Uwzględniając powyższe dane, sformułowano następujące hipotezy:

Hipoteza 2: Kobiety prezentują wyższy poziom przyjmowanej perspektywy, osobistej przykrości i empatycznej troski niż mężczyźni.

Style przywiązania wśród kobiet i mężczyzn istotnie różnią się, przede wszystkim w zakresie stylu lękowo-ambiwalentnego i unikowego, którego większe nasilenie prezentują kobiety (Plopa, 2016). Nie zauważono istotnych różnic 
pomiędzy kobietami a mężczyznami w zakresie stylu bezpiecznego. W związku z powyższym wysunięto hipotezę:

Hipoteza 3: Kobiety prezentują wyższe nasilenie stylu lękowo-ambiwalentnego i unikowego, niż mężczyźni.

\subsection{Rodzaj zawartego związku a empatia i style przywiązania}

Literatura przedmiotu przedstawia, że przyczynami przedkładania związku niezalegalizowanego (kohabitacyjnego) nad związek małżeński przez dorosłe osoby, mogą być określone postawy partnerów, ocena własnych perspektyw rozwojowych (charakter podmiotowy) lub kontekst społeczno-kulturowy (Janicka, 2006). Ponadto kohabitanci, jako osoby nielegalizujące związku partnerskiego, szczególnie dążą do zachowania niezależności i wolności (Chechliński, 1981). Natomiast w związku małżeńskim jednym z rodzajów zależności konstytuującym tenże związek jest zależność emocjonalna.

Relacje $\mathrm{w}$ bliskich związkach romantycznych ocenia się poprzez analizę czynników gwarantujących ich powodzenie (Janicka, 2008). Liczne badania i doniesienia z literatury wskazują na wyższy wskaźnik powodzenia wśród małżeństw aniżeli wśród związków niezalegalizowanych (Braun-Gałkowska, 2003; Rostowski, 1987). Badacze wskazują bardzo istotny czynnik cechujący związki małżeńskie, którym jest komunikacja. Komponentami komunikacji są empatia, otwartość i bliskość emocjonalna (Janicka, 2008).

W związku z powyższym autor zakłada, że:

Hipoteza 4: Związki małżeńskie częściej cechują style przywiązaniowe bezpieczne, aniżeli związki kohabitacyjne.

Hipoteza 5: Związki kohabitacyjne częściej charakteryzować będą style pozabezpiecznie, aniżeli małżeństwa.

Hipoteza 6: Osobista przykrość będzie bardziej charakterystyczna dla związków kohabitacyjnych, aniżeli dla związków małżeńskich.

\section{METODA}

\subsection{Charakterystyka wybranych narzędzi badawczych}

W badaniach wykorzystano Kwestionariusz Stylów Przywiązaniowych (KSP) M. Plopy oraz Skalę Wrażliwości Empatycznej (SWE) autorstwa M. Kaźmierczak, M. Plopy i S. Retowskiego. Pierwsze z tych narzędzi wykorzystano do ustalenia stylów przywiązaniowych w grupie osób badanych. Składa się on z dwóch wersji: dla kobiet oraz dla mężczyzn, zawierających po 24 stwierdzenia, które są oceniane na 7-punktowej skali Likerta. KSP zawiera trzy podskale odpowiadające trzem stylom przywiązaniowym (Plopa, 2016): 
1. styl bezpieczny - okazywanie wzajemnej czułości, przywiązania; wzajemne zaufanie, otwartość, przeświadczenie o wsparciu i życzliwości ze strony partnera, poczucie bezpieczeństwa, satysfakcja z bliskości;

2. styl lękowo-ambiwalentny - niepokój, obawa przed utratą partnera, wzmożona czujność, stany niepokoju nasilają się, gdy partner nie spełnia oczekiwań lub gdy zachowuje się niezgodnie z przeświadczeniem o uczuciowości, obniżone poczucie bezpieczeństwa, ,przewrażliwienie” na punkcie relacji ja-partner;

3. styl unikowy - brak tendencji do nawiązywania z partnerem bliskich relacji, wycofanie emocjonalne, brak intymności, zarysowana wyraźna granica emocjonalna.

Skala Wrażliwości Empatycznej składa się z 28 stwierdzeń, które oceniane są na 5-punktowej skali Likerta. Zawiera ona trzy podskale, dotyczące odrębnych aspektów empatii (Kaźmierczak i in., 2007):

- Podskale Przyjmowania Perspektywy (PP) - spontaniczne przyjmowanie innego punktu widzenia niż własny, umiejętność przewidywania reakcji i wczuwania się w emocje innych osób.

- Podskale Empatycznej Troski (ET) - skłonność do współczucia i współodczuwania osobom, które znajdują się w niekorzystnej sytuacji życiowej.

- Podskale Osobistej Przykrości (OP) - są to uczucia w głównej mierze zorientowane na siebie, skłonność do zamartwiania się, poczucia niepokoju, strachu, przykrości związanej z sytuacjami silnie negatywnymi.

\section{OSOBY BADANE}

Grupę badaną stanowiły osoby pozostające w bliskich związkach interpersonalnych, heteroseksualnych, takich jak: małżeństwo oraz kohabitacja. Badaniami objęto 60 par ( 38 związków kohabitacyjnych i 22 związki małżeńskie). Były to osoby znajdujące się w okresie wczesnej dorosłości - ramy czasowe okresu dorosłości przyjęto za Gruba (2000) - w wieku od 18 do 35 lat. Średni wiek kobiet wynosił 27,6 lat (odchylenie standardowe, standard deviation $-S D=4,43$ ), a u mężczyzn $29,61(S D=4,27)$. W badanej grupie przeważały osoby z wykształceniem wyższym $(32,5 \%)$ oraz średnim $(31,7 \%)$. Osoby badane pochodziły w większości z miast liczących od 100 do 500 tysięcy mieszkańców $(48,3 \%)$, następnie ze wsi (20\%), jednakże dokładne dane dotyczące miejsca zamieszkania nie były analizowane. Mimo że staż związku nie jest uwzględniony w analizie, autor pragnie zaznaczyć, że 47,5\% związków stanowią pary, które pozostają w bliskim związku od jednego roku do 5 lat, a 44,2\% stanowią pary, których staż w związku wynosi powyżej 5 lat, jednakże nie przekracza 10 lat. Badane związki zamieszkują wspólnie, a staż wspólnego zamieszkania wynosi w przypadku małżeństw $M=3,75(S D=0,44)$, a w przypadku związków kohabitacyjnych $M=2,04$ $(S D=1,21)$. 


\section{PRZEBIEG BADAŃ}

Próba osób badanych została w sposób celowy wyodrębniona z populacji. Podstawowym kryterium doboru grupy badanej był wiek mieszczący się w ramach grupy młodych dorosłych, wspólne zamieszkanie przez okres minimum jednego roku oraz pozostawanie w bliskim związku przez okres co najmniej dwóch lat. Mimo że staż związku w kontekście niniejszych badań nie jest uwzględniany, jednak był warunkiem włączenia badanych związków do grupy par kohabitujących. Zgodnie z definicją Trosta, Chechlińskiego oraz Wiersmana (za: Janicka, 2006; Kwak, 2005), wspólne zamieszkanie, bez zalegalizowanego związku i deklaracji narzeczeństwa, pozwala zaliczyć dany związek do formy związku kohabitującego.

Wszystkie osoby badane zostały poinformowane o naukowym charakterze prowadzonych badań oraz o ich anonimowości. Po wyrażeniu zgody przez daną parę przekazano osobom badanym kwestionariusze. W analizie uwzględniono tylko kompletnie wypełnione kwestionariusze.

\section{WYNIKI BADAŃ}

Poniżej zostaną zaprezentowane wyniki analiz korelacyjnych $r$-Pearsona oraz dwuczynnikowej, wielozmiennowej analizy wariancji.

Wyniki analiz korelacyjnych przedstawionych w tabeli 1 wskazały istotne statystycznie związki między trzema stylami przywiązania a poziomami dyspozycyjnej empatii. Wartości współczynnika korelacji wskazały na dodatnie związki pomiędzy stylem bezpiecznym a przyjmowaniem perspektywy. Styl lękowo-ambiwalentny koreluje dodatnio z empatyczną troską oraz osobistą przykrością. Styl unikowy koreluje dodatnio ze skalą osobistej przykrości oraz koreluje ujemnie ze skalą przyjmowania perspektywy. Potwierdzono tym samym hipotezę pierwszą o bezpośrednim związku między stylami przywiązania a poziomem empatii w związkach. W szczegółowej analizie nie potwierdzono hipotezy la o związku empatycznej troski z bezpiecznym stylem przywiązania. Potwierdzono związek osobistej przykrości z negatywnymi dla relacji stylami przywiązania, tj. stylem lękowo-ambiwalentnym i unikowym. Tym samym uzasadniono hipotezę $1 b$. Dane zaprezentowano w tab. 1.

Następnie, w celu zweryfikowania hipotezy o znaczeniu płci i rodzaju zawartego związku (małżeństwo vs. kohabitacja) dla empatii i stylów przywiązaniowych przeprowadzono dwuczynnikową, wielozmiennową analizę wariancji. Test wielu zmiennych wykazał istotne różnice dla czynnika płci (kobieta/ mężczyzna), lambda Wilksa $(l)=0,781 ; F(6,111)=5,201 ; p<0,001 ; h^{2}=0,219$. Oznacza to, że płeć różnicuje zmienne zależne analizowane łącznie. Ani rodzaj zawartego 
Tabela 1. Współczynnik korelacji $r$-Pearsona pomiędzy stylami przywiązania a wymiarami empatii $(N=120)$

\begin{tabular}{|c|c|c|c|}
\hline Style przywiązania $\quad$ Empatia & $\begin{array}{c}\text { Empatyczna } \\
\text { troska }\end{array}$ & $\begin{array}{l}\text { Osobista } \\
\text { przykrość }\end{array}$ & $\begin{array}{c}\text { Przyjmowanie } \\
\text { perspektywy }\end{array}$ \\
\hline Styl bezpieczny & 0,063 & $-0,083$ & $0,311^{* *}$ \\
\hline Styl lękowo-ambiwalentny & 0,199* & $0,264 * *$ & 0,028 \\
\hline Styl unikowy & 0,045 & $0,262 * *$ & $-0,207 *$ \\
\hline
\end{tabular}

$* \mathrm{p}<0,05 ; * * \mathrm{p}<0,01$

Źródło: opracowanie własne.

związku (małżeństwo/kohabitacja), ani efekt interakcji nie były istotnie statystycznie, a więc nie różnicują zmiennych zależnych analizowanych łącznie. Dane przedstawiono w tab. 2.

Tabela 2. Podsumowanie dwuczynnikowej analizy wariancji oszacowania znaczenia płci i rodzaju zawartego związku dla wymiarów empatii oraz stylów przywiązania

\begin{tabular}{|l|c|c|c|c|c|}
\hline \multicolumn{1}{|c|}{ Źródło efektu } & $\begin{array}{c}\text { Lambda } \\
\text { Wilksa }\end{array}$ & $d f$ & $F$ & $\eta^{2}$ & $p$ \\
\hline $\begin{array}{l}\text { Płeć } \\
\text { (kobieta } v s \text { mężczyzna) }\end{array}$ & 0,781 & 6,111 & 5,201 & 0,219 & $<0,001$ \\
\hline $\begin{array}{l}\text { Rodzaj } \\
\text { (małżeństwo vs kohabitacja) }\end{array}$ & 0,930 & 6,111 & 1,396 & 0,070 & 0,223 \\
\hline Płećx Rodzaj & 0,966 & 6,111 & 0,649 & 0,034 & 0,691 \\
\hline
\end{tabular}

W celu przeanalizowania szczegółowych różnic przeprowadzono testy efektów międzygrupowych. Czynnik płci istotnie różnicował dwa wymiary empatii emocjonalnej, tj. empatyczną troskę $F(1,116)=8,855 ; p<0,01 ; h^{2}=0,071$ oraz osobistą przykrość $F(1,116)=26,811 ; p<0,001 ; h^{2}=0,188$. Poziomy empatii emocjonalnej na wymiarze empatycznej troski i osobistej przykrości są wyższe dla kobiet (empatyczna troska: $M=35,37 ; S D=0,54$; osobista przykrość: $M=25,33 ; S D=0,59$ ) niż dla mężczyzn (empatyczna troska: $M=33,11 ; S D=0,54$; osobista przykrość: $M=21,17 ; S D=0,59)$. Nie stwierdzono u kobiet oraz mężczyzn istotnych różnic na wymiarze empatii poznawczej, a więc w przyjmowaniu perspektywy. Nie wykazano głównego efektu płci dla stylów przywiązaniowych.

Test efektów międzygrupowych wykazał istotne różnicowanie czynnika rodzaju zawartego związku dla stylu lękowo-ambiwalentnego $F(1,116)=4,777$; $p<0,05 ; h^{2}=0,04$ oraz dla osobistej przykrości $F(1,116)=4,911 ; p<0,05$; $h^{2}=0,041$. Wskaźnik stylu lękowo-ambiwalentnego jest istotnie wyższy dla związków kohabitacyjnych $(M=27,53 ; S D=1,30)$ niż dla związków małżeńskich $(M=22,84 ; S D=1,71)$. Wskaźnik osobistej przykrości jest istotnie wyższy dla związków kohabitacyjnych $(M=24,15 ; S D=0,49)$ niż dla związków małżeńskich $(M=22,36 ; S D=0,64)$. Szczegółowe dane przedstawiono w tabeli 3. 
Tabela 3. Wyniki podsumowania dwuczynnikowej analizy wariancji oszacowania wymiarów empatii i stylów przywiązania w zależności od płci osób badanych oraz rodzaju zawartego związku

\begin{tabular}{|c|c|c|c|c|c|}
\hline Źródło efektu & \multicolumn{5}{|c|}{ Style przywiązania } \\
\hline \multirow{4}{*}{ Rodzaj związku } & & $F$ & $d f$ & $\eta^{2}$ & $p$ \\
\hline & bezpieczny & 1,354 & 1,116 & 0,012 & 0,247 \\
\hline & lękowo-ambiwalentny & 4,787 & 1,116 & 0,040 & 0,031 \\
\hline & unikowy & 0,879 & 1,116 & 0,008 & 0,351 \\
\hline \multirow{4}{*}{ Płeć } & bezpieczny & 0,531 & 1,116 & 0,005 & 0,468 \\
\hline & lękowo-ambiwalentny & 0,147 & 1,116 & 0,001 & 0,702 \\
\hline & unikowy & 0,029 & 1,116 & 0,000 & 0,864 \\
\hline & \multicolumn{5}{|c|}{ Wymiary empatii } \\
\hline \multirow{4}{*}{ Rodzaj związku } & & $F$ & $d f$ & $\eta^{2}$ & $p$ \\
\hline & empatyczna troska & 0,388 & 1,116 & 0,003 & 0,535 \\
\hline & osobista przykrość & 4,911 & 1,116 & 0,041 & 0,029 \\
\hline & $\begin{array}{l}\text { przyjmowanie } \\
\text { perspektywy }\end{array}$ & 0,011 & 1,116 & 0,000 & 0,918 \\
\hline \multirow{3}{*}{ Płeć } & empatyczna troska & 8,855 & 1,116 & 0,071 & 0,004 \\
\hline & osobista przykrość & 26,811 & 1,116 & 0,188 & $<0,001$ \\
\hline & $\begin{array}{l}\text { przyjmowanie } \\
\text { perspektywy }\end{array}$ & 1,588 & 1,116 & 0,014 & 0,210 \\
\hline
\end{tabular}

Tabela 4 przedstawia zestawienie średnich ocen uzyskanych przez związki małżeńskie i kohabitacyjne dla wymiarów empatii i stylów przywiązaniowych odpowiednio dla kobiet oraz dla mężczyzn.

Tabela 4. Średnie wartości stylów przywiązania i wymiarów empatii w zależności od rodzaju zawartego związki oraz płci

\begin{tabular}{|c|c|c|c|c|}
\hline Style przywiązania & Rodzaj związku & Płeć & $M$ & $S D$ \\
\hline 1 & 2 & 3 & 4 & 5 \\
\hline \multirow{4}{*}{ Bezpieczny } & \multirow{2}{*}{ kohabitacja } & kobieta & 45,658 & 1,390 \\
\hline & & mężczyzna & 43,474 & 1,390 \\
\hline & \multirow{2}{*}{ małżeństwo } & kobieta & 46,545 & 1,827 \\
\hline & & mężczyzna & 46,364 & 1,827 \\
\hline \multirow{4}{*}{ Lękowo-ambiwalentny } & \multirow{2}{*}{ kohabitacja } & kobieta & 28,237 & 1,841 \\
\hline & & mężczyzna & 26,842 & 1,841 \\
\hline & \multirow{2}{*}{ małżeństwo } & kobieta & 21,318 & 2,420 \\
\hline & & mężczyzna & 24,364 & 2,420 \\
\hline \multirow{4}{*}{ Unikowy } & \multirow{2}{*}{ kohabitacja } & kobieta & 18,184 & 1,441 \\
\hline & & mężczyzna & 17,789 & 1,441 \\
\hline & \multirow{2}{*}{ małżeństwo } & kobieta & 16,500 & 1,894 \\
\hline & & mężczyzna & 16,318 & 1,894 \\
\hline
\end{tabular}




\begin{tabular}{|c|c|c|c|c|}
\hline 1 & 2 & 3 & 4 & 5 \\
\hline \multicolumn{5}{|c|}{ Wymiary empatii } \\
\hline \multirow{4}{*}{ Empatyczna troska } & \multirow{2}{*}{ kohabitacja } & kobieta & 36,237 & 0,651 \\
\hline & & mężczyzna & 32,711 & 0,651 \\
\hline & \multirow{2}{*}{ małżeństwo } & kobieta & 34,500 & 0,856 \\
\hline & & mężczyzna & 33,500 & 0,856 \\
\hline \multirow{4}{*}{ Osobista przykrość } & \multirow{2}{*}{ kohabitacja } & kobieta & 26,579 & 0,688 \\
\hline & & mężczyzna & 21,711 & 0,688 \\
\hline & \multirow{2}{*}{ małżeństwo } & kobieta & 24,091 & 0,905 \\
\hline & & mężczyzna & 20,636 & 0,905 \\
\hline \multirow{4}{*}{ Przyjmowanie perspektywy } & \multirow{2}{*}{ kohabitacja } & kobieta & 30,579 & 0,732 \\
\hline & & mężczyzna & 29,289 & 0,732 \\
\hline & \multirow{2}{*}{ małżeństwo } & kobieta & 30,455 & 0,962 \\
\hline & & mężczyzna & 29,591 & 0,962 \\
\hline
\end{tabular}

\section{DYSKUSJA}

\subsection{Empatia a style przywiązania}

Wyniki zaprezentowanego badania wskazują istotne powiązania dyspozycyjnej empatii ze stylami przywiązania. Przyjmowanie perspektywy korelowało dodatnio ze stylem bezpiecznym. Empatyczna troska oraz osobista przykrość korelowały dodatnio ze stylem lękowo-ambiwalentnym. Styl unikowy korelował dodatnio z osobistą przykrością oraz korelował ujemnie z przyjmowaną perspektywą. Ponadto, wyniki badania stanowią podstawę do dalszego prowadzenia bardziej wnikliwych analiz dotyczących znaczenia moderatorów, tj. cech osobowości czy satysfakcji ze związku dla zależności pomiędzy empatią a stylami przywiązaniowymi. W literaturze wskazać można lukę empiryczną i teoretyczną, dotyczącą zależności między interesującymi autora zmiennymi, a więc dyspozycyjną empatią, a stylami przywiązania. Literatura wskazuje korzystne znaczenie empatycznej troski i przyjmowania perspektywy dla tworzenia trwałych i bliskich związków. Zwłaszcza eksponuje się znaczenie poznawczego komponentu empatii dla zwiększonej tendencji do udzielania wsparcia partnerowi (Kaźmierczak, 2008). Badacze Long i Andrews (1990) wnioskują o ogromnej roli przyjmowania perspektywy dla trwałości i jakości związku małżeńskiego. Ponadto poznawczy komponent empatii pozwala na lepsze zrozumienie partnera, chęci wspierania go, a także zacieśniania więzi psychicznej między partnerami. Wyniki dokumentujące powiązania między stylem bezpiecznym a przyjmowaniem perspektywy wydają się zasadne i poparte literaturą (Wojciszke, 2014), gdyż podkreśla się skłonność przyjmowania cudzej perspektywy dla poprawy ogólnej satysfakcji ze związku. 
Przede wszystkim w zakresie uniknięcia negatywnych zjawisk i procesów, takich jak nietolerancja, sztywność czy konflikty.

Nie można zapominać, że przyjmowanie perspektywy jest także komponentem empatii skłaniającym się w kierunku negatywnej oceny osoby, która skutkuje destrukcyjnym zachowaniem wobec niej. Badania wykazały ujemną korelacje między stylem unikowym a przyjmowaniem perspektywy. Osoby o stylu unikowym preferują wyalienowany styl życia, nawet jeżeli pozostają w bliskim związku to nie potrafią nawiązywać intymnych relacji. Osoby takie często charakteryzuje poirytowanie, zażenowanie czy zdenerwowanie $\mathrm{w}$ reakcji na zachowania partnera, które świadczą o chęci nawiązania bliskości. Ujemna korelacja powyższego stylu z przyjmowaniem perspektywy znajduje pośrednio swoje uzasadnienie w literaturze (Rembowski, 1989; Dymond, 1948, 1949). Często programy terapeutyczne radzenia sobie $\mathrm{z}$ destruktywnymi czy agresywnymi zachowaniami uwzględniają poznawczy komponent empatii, jakim jest przyjmowanie perspektywy. W związku z powyższym uzyskane wyniki mają walor aplikacyjny, gdyż niskie wskaźniki przyjmowania perspektywy są predykatorem dla zachowań unikowych. Osobista przykrość, która także korelowała ze stylem unikowym, jest komponentem empatii emocjonalnej, składającym się na przejmowanie cudzych, negatywnych emocji. Ponadto jednostka ma mniejsze możliwości regulacji emocjonalnej, które mogą prowadzić do ryzyka zaburzeń w obszarze osobowości (Pastwa-Wojciechowska i in., 2015).

Empatyczna troska i osobista przykrość korelowały dodatnio ze stylem lękowo-ambiwalentnym. Jak wspomniano wcześniej, osobista przykrość związania jest $\mathrm{z}$ brakiem lub słabą umiejętnością radzenia sobie $\mathrm{z}$ negatywnymi uczuciami. Empatyczna troska natomiast jest silnie powiązania z postawą altruistyczną (Batson, 1991). Osoby, które cechuje styl lękowo-ambiwalentny, na ogół odczuwają niepokój oraz cierpią z powodu niedostatecznego okazywania przez partnera miłości. Przede wszystkim wynika to z obniżonego poczucia bezpieczeństwa (Plopa, 2016). Osoby lękowo-ambiwalentne potrafią okazywać uczucia w stosunku do partnera, są też osobami współodczuwającymi, ale w wyniku zaburzonego wizerunku relacji ja-partner często przeżywają wewnętrzne rozterki. Wyniki przedstawionego badania wskazały silniejszy związek osobistej przykrości ze stylem lękowo-ambiwalentnym aniżeli empatycznej troski. Taki stan rzeczy odnajduje swoje odzwierciedlenie w zachowaniach osób lękowo-ambiwalentnych.

\subsection{Płeć i rodzaj zawartego związku a poziom empatii i style przywiązaniowe}

Wyniki badania częściowo pozwalają na potwierdzenie hipotezy 2, zakładającej, że kobiety wykazują wyższy poziom na wszystkich wymiarach empatii niż mężczyźni. Dane dostarczyły informacji o większej empatii emocjonalnej kobiet 
niż mężczyzn na wymiarach empatycznej troski oraz osobistej przykrości. Wyniki te pokrywają się z doniesieniami z literatury, mówiącymi o wyższej wrażliwości emocjonalnej kobiet aniżeli mężczyzn (Cross, Marcus, 2004; Janicka, Niebrzydowski, 1994). Badanie nie wykazało różnic płciowych na wymiarze przyjmowania perspektywy. Również nie wykazano różnic w stylach przywiązaniowych zarówno u kobiet, jak i u mężczyzn. Z pewnością warto przeprowadzić bardziej szczegółowe badania na temat znaczenia czynników kontekstowych czy socjodemograficznych dla stylów przywiązaniowych.

Rodzaj zawartego związku istotnie różnicował lękowo-ambiwalentny styl przywiązania oraz poziom osobistej przykrości na korzyść związków kohabitacyjnych. Literatura podaje, że wyższe natężenie skali osobistej przykrości sprzyja niskiej samoocenie, lękowi, niepewności i wrażliwości emocjonalnej, która może sprzyjać nieadaptacyjnemu funkcjonowaniu społecznemu (Davis, 1983), w tym także funkcjonowaniu w związku. W przypadku stylów przywiązaniowych w bliskich relacjach mediatorem pomiędzy tą zmienną a empatią może być satysfakcja ze związku lub czynniki dotyczące różnic indywidualnych (Kaźmierczak, 2008). Zasadnicza różnica wynikająca z powyższych doniesień sugeruje, że styl lękowo-ambiwalentny jest bardziej charakterystyczny dla związków kohabitacyjnych, aniżeli dla związków małżeńskich. Ponadto w związkach osób kohabitujących wyróżniono wyższy wskaźnik osobistej przykrości, aniżeli w związkach małżeńskich.. Wyniki uzyskane w badaniu przyczynią się do dalszej eksploracji nurtujących autora pytań.

Liczne badania empiryczne potwierdzają znaczenie empatii i bliskości emocjonalnej dla powodzenia bliskich związków, a w szczególności związków małżeńskich (Rostowski, Rostowska, 2014; Rostowski, 1987; Braun-Gałkowska, 1992; Janicka, 2006), co dodatkowo podkreślają wyniki wskazujące, że partnerzy kohabitujący charakteryzują się większymi skłonnościami do konfliktów niż małżonkowie (Thomson, Colelle, 1992).

\section{BIBLIOGRAFIA}

Ainsworth M. D. S. (1977). Infant Development and Mother-infant Interaction Among Ganda and American Families. [W:] P. H. Leiderman, S. R. Tulkin, A. Rosenfield (red.), Culture and Infancy (s. 119-149). New York: Academic Press.

Baron-Cohen S. (2014). Teoria zła. O empatii i genezie okrucieństwa. Sopot: Smak Słowa.

Bowlby J. (2007). Przywiazanie. Warszawa: Wydawnictwo Naukowe PWN.

Braun-Gałkowska M. (1992). Psychologiczna analiza systemów rodzinnych osób zadowolonych i niezadowolonych z matżeństwa. Lublin: Towarzystwo Naukowe Katolickiego Uniwersytetu Lubelskiego.

Braun-Gałkowska M. (2003). Miłość aktywna. Psychiczne uwarunkowania powodzenia matżeństwa. Warszawa: Instytut Wydawniczy PAX.

Batson C. D. (1991). The Altruism Question: Toward a Social - Psychological Answer. Hillsdale: Lawrence Erlbaum Associates. 
Chechliński W. (1981). Kohabitacja - nowe zjawisko życia rodzinnego. [W:] M. Ziemska, A. Kwak (red.), Funkcjonowanie rodziny a problemy profilaktyki społecznej i resocjalizacji. Warszawa: Wydawnictwo Uniwersytetu Warszawskiego.

Cross S. E., Markus H. R. (2004). Płeć w myśleniu, przekonaniach i działaniu: podejście poznawcze (s. 48-80). [W:] B. Wojciszke (red.), Kobiety i mężczyźni: odmienne spojrzenia na różnice. Gdańsk: Gdańskie Wydawnictwo Psychologiczne.

Czerniakowska M. (2002). Empatia a system wartości. Przegląd Psychologiczny, 45 (1), 7-18.

Davis M. H. (1980). A multidimensional approach to individual differences in empathy. JSAS Catalog of S lected Documents in Psychology, 10 (85).

Davis M. H. (1983). Measuring individual differences in empathy: Evidence for a multidimensional approach. Journal of Personality and Social Psychology, 44 (1), 113-126.

Davis M. H. (1999). Empatia. O umiejętności współodczuwania. Gdańsk: Gdańskie Wydawnictwo Psychologiczne.

Davis M. H., Oathout H. A. (1987). Maintenance of satisfaction in romantic relationships: empathy and relational competence. Journal of Personality and Social Psychology, 53, 397-410.

Dymond R. F. (1949). A scale for the measurement of empathic ability. Journal of Consulting Psychology, 13, 127-133.

Dymond R. F. (1948). A preliminary investigation of the relation of insight and empathy. Journal of Consulting Psychology, 12, 228-233.

Eisenberg N., Fabes R. A. (1992). Emotion, regulation, and the development of social competence. [W:] M. S. Clark (red.), Review of Personality and Social Psychology: Emotion and Social Behaviour (t. 14, s. 119-150). Newbury Park: Sage.

Eisenberg N., Lennon R. (1983). Sex differences in empathy and related capacities. Psychological Bulletin, 94, 100-131.

Feldman R., Greenbaum, C. W., Yirmiya N. (1999). Mother-infant affect synchrony as an antecedent of the emergence of self-control. Developmental Psychology, 35, 223-231.

Gruba E. (2000). Wczesna dorosłość. [W:] B. Harwas-Napierała, J. Trempała (red.), Psychologia rozwoju czlowieka (t. 2, s. 202-233). Warszawa: Wydawnictwo Naukowe PWN.

Hazan C., Shaver P. R. (1994). Attachment as an Organizational Framework for Research on Close Relationships. Psychological Inquiry, 5, 1-22.

Janicka I. (2006). Kohabitacja a matżeństwo w perspektywie psychologicznej. Studium porównawcze. Łódź: Wydawnictwo Uniwersytetu Łódzkiego.

Janicka I. (2008). Stosunki partnerskie w związkach niemałżeńskich. Przegląd Psychologiczny, 51(1), 37-53.

Janicka I., Niebrzydowski L. (1994). Psychologia małzeństwa, Zafascynowanie partnerem. Otwartość. Empatia. Miłość. Seks. Łódź: Wydawnictwo Uniwersytetu Łódzkiego.

Józefik B., Iniewicz G. (red.). (2008). Koncepcja przywiąania. Od teorii do praktyki klinicznej. Kraków: Wydawnictwo Uniwersytetu Jagiellońskiego.

Kaźmierczak M. (2008). Oblicza empatii w relacjach matżeńskich. Perspektywa psychologiczna. Gdańsk: Wydawnictwo Uniwersytetu Gdańskiego.

Kaźmierczak M., Plopa M. (2006). Style przywiązaniowe a jakość komunikacji w małżeństwie. Psychologia Rozwojowa, 4, 115-126.

Kaźmierczak M., Plopa M., Retowski S. (2007). Skala wrażliwości empatycznej. Przegląd Psychologiczny, 50(1), 9-24.

Kestenbaum R., Farber, E. A., Sroufe L. A. (1989). Individual differences in empathy among preschoolers: Relation to attachment history. New Directions for Child and Adolescent Development, (44), 51-64.

Kwak A. (2005). Rodzina w dobie przemian. Matżeństwo i kohabitacja. Warszawa: Wydawnictwo Akademickie „Żak”. 
Liberska H., Suwalska D. (2011). Styl przywiązania a relacje partnerskie we wczesnej dorosłości. Psychologia Rozwojowa, 16 (1), 25-39.

Long E. C., Andrews D. W. (1990). Perspective taking as a predictor of marital adjustment. Journal of Personality and Social Psychology, 59, 126-131.

Miculincer M. (1998). Attachment Working Models and the Sense of Trust: An Exploration of Interaction Goals and Affect Regulation. Journal of Personality and Social Psychology, 74 (5), 1209-1224.

Pastwa-Wojciechowska B., Kaźmierczak M., Błażek M. (2015). Empatia a postawy wobec przemocy - doniesienia z badań. Folia Psychologica, 19, 141-153.

Plopa M. (2003). Intymność a ,jej” i ,jego” satysfakcja ze związku małżeńskiego. [W:] I. Janicka, T. Rostowska (red.), Psychologia w stużbie rodziny (s. 32-44). Łódź: Wydawnictwo Uniwersytetu Łódzkiego.

Plopa M. (2016). Więzi w matżeństwie i rodzinie. Metody badań. Kraków: Oficyna Wydawnicza Impuls.

Rembowski J. (1989). Empatia. Warszawa: PWN.

Rostowski J. (1987). Zarys psychologii malżeństwa. Warszawa: PWN.

Rostowski J. (2003). Style przywiązania a kształtowanie się związków interpersonalnych w rodzinie. [W:] I. Janicka, T. Rostowska (red.), Psychologia w stużbie rodziny (s. 19-31). Łódź: Wydawnictwo Uniwersytetu Łódzkiego.

Rostowski J., Rostowska T. (2014). Matzeństwo i miłość. Kontekst psychologiczny i neuropsychologiczny. Warszawa: Wydawnictwo Difin.

Sternberg R. J. (1986). A triangular theory of love. Psychological Review, 93 (2), 119-135.

Sternberg R .J. (1997). Construct validation of a triangular love scale. European Journal of Social Psychology, 27 (3), 313-335.

Sternberg R .J. (2001). Empirical tests of aspects of a theory of love as a story. European Journal of Personality, 15, 199-218.

Tarabulsy G. M., Tessier R., Gagnon J., Pieche C. (1996). Attachment classification and infant responsiveness during interactions. Infant Behaviour and Developments, 19, 131-143.

Thomson E., Colelle U. (1992). Cohabitation and Marital Stability: Quality or Commitment. Journal of Merriage and the Family, 54, 259-268.

Waters E., Wippman J., Sroufe L. A. (1979). Attachment, Positive Affect, and Competence in the Peer Group: Two Studies in Construct Validation. Child Development, 50 (3), 821-829.

Wojciszke B. (2004). Człowiek wśród ludzi. Zarys psychologii społecznej. Warszawa: Wydawnictwo Naukowe „Scholar”.

Wojciszke B. (2014). Psychologia miłości. Gdańsk: Gdańskie Wydawnictwo Psychologiczne.

\title{
JUSTYNA KULCZYK
}

\section{EMPATHY AND ATTACHMENT STYLE IN THE CONTEXT OF CLOSE RELATIONSHIPS OF YOUNG ADULTS}

\begin{abstract}
In the present article there has been described a connection between three dimensional model of empathy and attachment styles in close relationships of young adults. The study was conducted in a group of 120 people (60 women, 60 men; 38 cohabitant pairs, 22 marriages). The participants filled in the following questionnaires: The Scale of Empathic Sensitiveness, which measures empathic concern, personal distress and perspective taking, and The Questionnaire of
\end{abstract}


Attachment Styles, which measures the following styles: the secure style, the anxious-ambivalent style and the avoidant style. The results indicate that there exists a connection between empathy and attachment styles. The secure style correlates positively with perspective taking, the anxious-ambivalent style correlates positively with empathic concern and personal distress, the avoidant style correlates positively with personal distress and negatively with perspective taking. The study revealed that women achieved higher scores on empathic concern and personal distress than men did, but no sex differences in manifested attachment styles were observed. Moreover, the type of relationship (marriage vs. cohabitation) differentiated scores on the anxious-ambivalent style and personal distress dimension, where cohabitants scored higher.

Keywords: attachment styles, empathy. 